doi: 10.18575/msrs.sm.e.18.05 UDC: $616.37-002.1-07$ COBISS.RS-ID:7317272

\section{Complications of Treatment of Acute Pancreatitis}

\begin{abstract}
Introduction: Acute pancreatitis is non specific inflammation of the pancreas due to the intrapancreatic activation of its proteolytic and lipolytic enzymes enzyme lesions. The enzymes normally excreted by the pancreas are activated in the pancreas and destroy its tissue, leading to an autolysis process that causes bleeding and damage to the blood vessels. Enzyme autodigestion begins with local inflammation, edema, bleeding and necrosis.
\end{abstract}

Aim of the Study: The aim of this paper is to determine the incidence and complications in patients with acute pancreatitis and on the basis of the results obtained define specific health care measures for prevention and suppression of complications.

Patients and Methods: This study included patients, suffering from acute pancreatitis, treated at the Clinic for General and Abdominal Surgery of UCCof the Republic of Srpska in Banja Luka, in the period from January 1st, 2015 until April 30th, 2017. The total number of patients treated in this period is 147. Diagnosis of the disease is based on a detailed anamnesis at the entrance (acute abdominal pain in all patients), laboratory examinations (complete blood images, C-reactive protein, amylase, and lipase) and diagnostic procedures (abdominal ultrasound examination, chest RTG, CT, ERCP, NMR and ECG). Based on the data obtained from the history of the disease, protocols and release lists, the following statistical analyses were performed: frequency of complications was established as well as mortality in billiary, alcoholic and idiopathic types of acute pancreatitis.

Results: The examinations performed determined the minimum number of laboratory and diagnostic procedures that confirm the acute pancreatitis diagnosis within a short period of time. The leading symptom of admission was a strong abdominal pain, present in all patients. Laboratory trials are dominated in elevated values of the total number leukocytes, C-reactive protein (CRP), and serum levels of amylase, lipase and bilirubin. Early diagnostic procedures, within the first 48 hours, significantly contribute to the reduction of acute pancreatitis complications. Out of a total of 147 patients with this diagnosis, 110 patients were treated conservatively and 27 operatively. Eight patients had a mortal outcome. By type of acute pancreatitis, billiary form is in the first, idiopathic second and alcoholic form in the third place. The mild clinical form of acute pancreatitis was present in 124 patients and severe in 23. Mortality rate was $5.44 \%$ in all three clinical forms.

Conclusion: Early confirmation of acute pancreatitis diagnosis is the basic prerequisite of disease progression, reduction of possible complications, and death as an outcome of the disease. Patients who were treated conservatively had a lower rate of complications, shorter hospital stay, faster recovery and better quality of life in the later period. Multidisciplinary approach to diagnosis and treatment patients suffering from acute pancreatitis significantly reduces morbidity and mortality. Quality and comprehensive health care, as part of multidisciplinary team work, contributes to reducing disease complications and faster recovery of the patient. The results of treatment of acute pancreatitis patients at UCC RS do not differ significantly from the results of treatment in similar institutions in the region and the world.

Key words: acute pancreatitis, therapy, complications

(Scr Med 2018:49:30-36)
Božo Krivokuća ${ }^{1}$, Milica Latinovićc', Svetozar Krivokućá ${ }^{1}$

${ }^{1}$ University Clinical Centre of the Republic of Srpska, Banja Luka ${ }^{2}$ Primary Health Care Centre, Banjaluka

\section{Contact address:}

Božo Krivokuća, Street address: Kolubarska 17, 78 ooo Banjaluka Republic of Srpska Bosnia and Herzegovina e-mail: bozokrivokuca@gmail.com phone number: +387-65-516-859
Submitted: March 13 $3^{\text {th }}, 2018$ Accepted: March 19 ${ }^{\text {th }}, 2018$ 


\section{Introduction}

Acute pancreatitis is a growing problem in Europe and North America. Incidence of the acute pancreatitis is 40$102 / 100$ ooo in countries where alcohol is consumed intensively, particularly at weekends, such as in Finland. Incidence is different all over the world and due to various aetiological factors. It ranges from 5.4 to 73.4 per 100 ooo inhabitants with a low incidence in England and the Netherlands, middle in Germany and Scotland, and exceptionally high in North America and Finland. The incidence of alcoholic pancreatitis is higher in males, and biliary type in females. In recent years, the incidence of diagnosed acute pancreatitis has increased in Western Europe countries. In developed countries, there are several reasons for these indicators about the increase in acute pancreatitis (AP). The main reason for this is the increase in diagnosed cholelitiasis syndrome as well as the increase in alcohol consumption and better diagnostic procedures (CT, endoscopic US, NMR and others). Although the incidence of disease increases, mortality is down due to improved diagnostic and therapeutic procedures. Based on some studies there was a fall in mortality in the last years between $2 \%$ and $11.4 \%$ $\cdot{ }^{1-3}$

Acute pancreatitis is the autoimmune process caused by the activation of zymogens in the active proteolytic enzymes within the pancreas. The causes of the activation of this process are still unclear. ${ }^{4}$

The gold standard for diagnosing of AP is the determination of serum pancreatic enzymes (serum amylases and urine and lipase).5,6 If lipase is 2.5-3 times higher than the physiological value it indicates alcoholic pancreatitis. ${ }^{7}$ Other laboratory tests for the diagnoses of AP are important values: CRP (C-reactive protein), hemoglobin, hematocrit, leukocytes, platelets, bilirubin, creatinine, urea, glucose, cholesterol, albumin, potassium, sodium, coagulation factor, chloride, acidbase status, TNF- tumor necrosis factor), cytokines. ${ }^{8}$

Ultrasound (US) of the abdomena is the first line of search to determine the AP etiology and to track the development and course of the disease. ${ }^{9}$ US is a non-invasive method, does not expose the patient to radiation, is fast and the first elementary indicator to assess the clinical image weight of AP. ${ }^{10}$

The second line of search is computerized tomography (CT). If the US could not confirm the diagnosis with certainty, because meteorism or adiposity of the patient, CT is the choice. A pancreatic presentation is provided and should be used in case of doubt in the severe form of AP as well as in all cases of unclear diagnosis. ${ }^{11}$
Based on the CT recordings, Baltazar and all. have developed the CT index of the weight of the image clinic, by which the morphological assessment of the AP. ${ }^{12}$

Nuclear magnetic resonance has several advantages over the CT to confirm the diagnosis and determine the complications. With NMR there is no risk of radiation, the contrast has little unwanted effects and is not nephrotoxic. ${ }^{13,14}$

\section{ERCP (Endoscopic Retrograde Cholangio-} Pancreatography) has a diagnostic and prophylactic purpose. This study visualises gallbladder stems, which can then be removed by papillotomy. ${ }^{15}$ Severe forms of pancreatitis by ERCP reduce morbidity and mortality. ${ }^{16}$

Acute pancreatitis is non specific inflammation of the pancreas due to the intrapancreatic activation of its proteolytic and lipolytic enzymes - enzyme lesions. The enzymes normally excreted by the pancreas are activated in the pancreas and destroy its tissue, leading to an autolysis process that causes bleeding and damage to the blood vessels. Enzyme autodigestion begins with local inflammation, edema, bleeding and necrosis. The most common causes of acute pancreatitis are: gall bladder stones, viral infections (parotitis, coxsackie B virus), bacterial infections (Mycoplasma pneumoniae, Campylobacter), injuries, pancreatic or gall bladder operations, alcohol and some medications.

The severe form of acute pancreatitis is characterized by the development of local and systemic complications. Local complications include: pancreatic pseudocysts, necrosis, fistula development, and ascites formation, while systemic factors include: infection, hypotension, acute kidney failure, respiratory failure, cardiac insufficiency, gastrointestinal bleeding and the development of disseminated intravascular coagulation (DIC). Acute pancreatitis with multiple organic disorders ends with fatalities. ${ }^{17}$

Every year, a large number of papers on acute pancreatitis are published in the world, new conclusions are made and the papers are published in modern treatment, they are sharing experiences, which in itself speaks of the seriousness of this difficult problem which can often be an enigma. Based on these findings, today we distinguish two forms of acute pancreatitis: acute interstitial pancreatitis and acute necrotary pancreatitis. Despite early recognition and adequate treatment of acute pancreatitis and its complications, mortality remains very high. In late stages, patients die due to infections. The highest mortality in patients with infected necrosis of the pancreas is between 30 and $60 \%$, while in sterile necrosis mortality ranges from o to $11 \% .^{18}$ 
Based on the clinical picture, laboratory, diagnostic and other parameters, the treatment is determined. There is a number of recommendations at the national and international level, as well as by gastroenterology associations, but there is still no specific causative therapy for this disease. Treatment begins with aggressive fluid replacement, correction of metabolic disorders, good analgesia and the treatment of local and systemic complications. Early and timely detection and recognition of complications is the key to proper treatment. AP requires treatment by multidisciplinary teams of doctors of various specialties as well as intervention and comprehensive health care by health professionals. On the basis of all relevant findings, a therapy that can be conservative and operative. These two therapies are mutually complementary. ${ }^{19}$

The mild to medium heavy form of the AP is treated at the surgical department, and is difficult in the intensive care unit of the surgery, with complete monitoring of the patient, which implies the establishment of a central venous pathway, measurement of central venous pressure (CVP), electrocardiography (ECG), arterial blood pressure (TA), diuresis, gas analyzes, breathing frequencies, blood count monitoring and biochemical analysis, temperature of the body. The mild and medium heavy forms have a mortality of $0-3 \%$, uninfected necrotic pancreatitis up to $10 \%$, and necrotic AP about $25-30 \%$. The general mortality is $2-10 \%{ }^{13}$

The therapy of severe pancreatic disorders is largely surgical procedure. ${ }^{17}$ Greenberg et al. states that serum lipase has a higher sensitivity to detect acute pancreatitis than serum amylase..$^{20}$ Values of antistreptolysin titre (AST), alanine transaminase (ALT), urea and bilirubin may be elevated, but are not significant for the detection of acute pancreatitis. Cholecystectomy is the most important of operative interventions. ${ }^{21}$ The most common local complication is retroperitoneal abscesses, while the most common systemic complications are respiratory and cardiovascular. ${ }^{22}$

\section{Aim of the Study}

Determine the incidence of complications (morbidity) and mortality in the case of biliary, alcoholic and idiopathic types of acute pancreatitis and on the basis of the results, define specific health care measures for the prevention and suppression of the complications.

\section{Patients and Methods}

The study included patients with acute pancreatitis who were treated at the University Clinical Centre of the Republic of Srpska in Banja Luka, at the Clinic for
General and Abdominal Surgery. The sample includes 147 patients who were treated in the period from January $1^{\text {st }}, 2015$ until May $1^{\text {st }}$, 2017. with the diagnosis of acute pancreatitis. Of the 147 patients analyzed, 94 (63.90\%) were male and $53(36.05 \%)$ female. Most patients had an mild-to-moderate form of acute pancreatitis, 124 patients (84.4\%), while 23 patients (15.6\%) had severe acute pancreatitis. The examination was conducted with respect to the Helsinki Declaration on Medical Research, with the prior consent of the Ethics Committee of the University Clinical Centre of the Republic of Srpska. The study was a retrospective-prospective study lasting 28 months, involving detailed data collection from the history of the disease and the protocols of the department. Evaluation of the obtained results, with all relevant parameters, was processed statistically and presented graphically.

Due to the way of processing, and with respect to the principles of credibility, all survey data were presented in electronic form. The obtained results, in accordance with the set objectives of the research, were statistically processed and analyzed using the appropriate standards and processing programs. When processing the data, each patient is provided with anonymity.

Different methods of interferential statistical processing tested and concluded implicit research hypotheses about the existence of differences between different methods of treatment of acute pancreatitis in relation to statistically credible research parameters.

During statistical processing, descriptive statistics of all patients by individual categories were first made, and then a comparison between two or more different categories according to the research objectives.

\section{Results}

Out of a total of 147 patients with AP, 124 or $84.4 \%$ had a mild to moderate clinical picture, while 23 or $15.6 \%$ had a severe clinical picture.

Of the 19 patients ranked according to the GLASGOW score scale, they were all in the range of $6-15$. Most of them were biliary type (12), out of which 1 patient was in a heavy coma, 4 in a middle difficulty coma and 3 patients in a shallow coma. Then there is an idiopathic type with 5 patients, of whom 2 were in the middle heavy coma and 3 in the shallow coma. In the end, the alcoholic type were two patients, of which 1 was in a medium heavy coma, and 1 in a shallow coma.

One patient was in a heavy coma, 7 patients in a middleaged coma and 11 patients in a shallow coma. (Chart 1.) 
Chart 1. Patients Ranked According to the Glasgow Comma Scores for Billiard, Alcoholic and Idiopathic AP Types

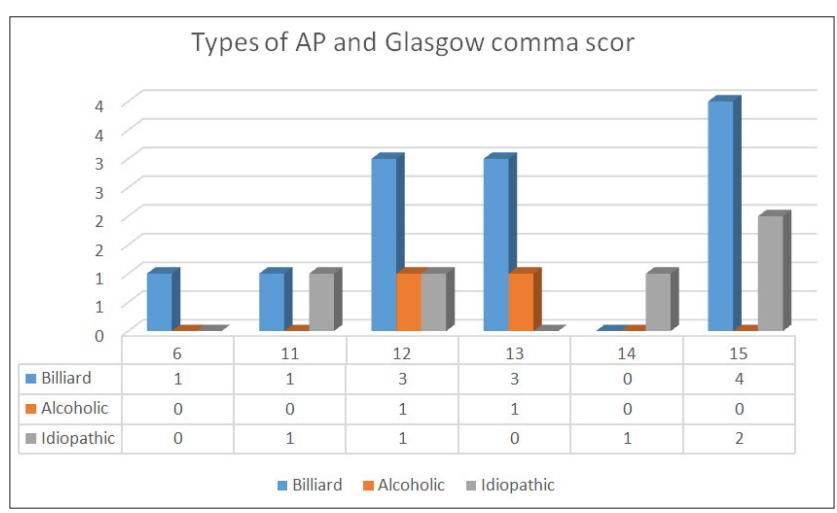

Out of the total analyzed 147 patients, 110 patients or $74.83 \%$ were treated conservatively, 27 or $18.37 \%$ were treated operatively, 8 patients or $5.44 \%$ were with death and 2 patients or $1.36 \%$ had been relocated to other departments. Of 8 patients with mortality, 5 were treated conservatively and 3 patients operatively. Three patients scheduled for surgery failed to give written consent and were not operated. (Chart 2.)

Chart 2. Outcome Treatment of Patients with Patients Exposed Treatment Conservative and Operative Procedures

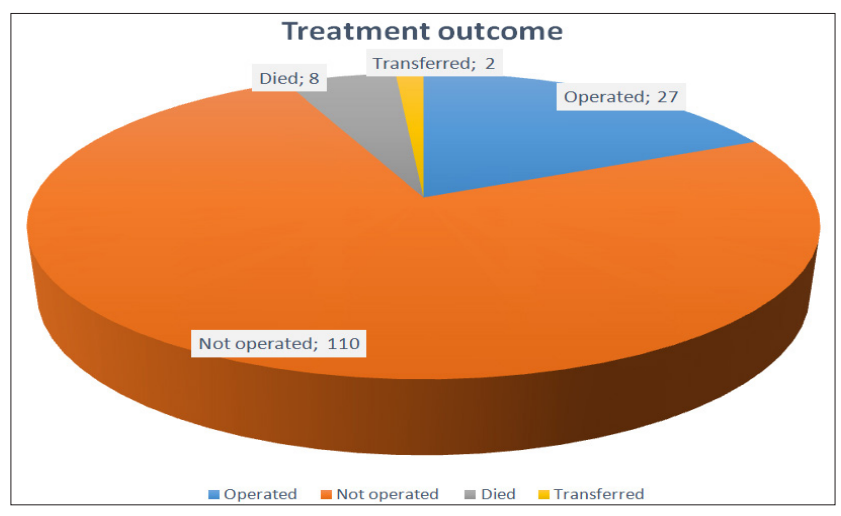

The most complications are in the biliary type AP (12.24\%), followed by idiopathic type AP (10.20\%) and alcohol type AP (2.04\%). Out of a total of 147 patients with AP, 66 were biliary (18 with complications, 48 without complications), 25 alcoholic (3 with complications, 22 without any complications), 56 idiopathic (15 with complications, 41 without any complications). The most common complications are ascites, pleural effusion, renal insufficiency, respiratory failure, cardiac insufficiency and combinations of combined complications in systemic failure of vital organs. (Chart 3.)
Chart 3. Frequency of Complications (Morbidity) in Biliary, Alcoholic and Idiopathic AP types

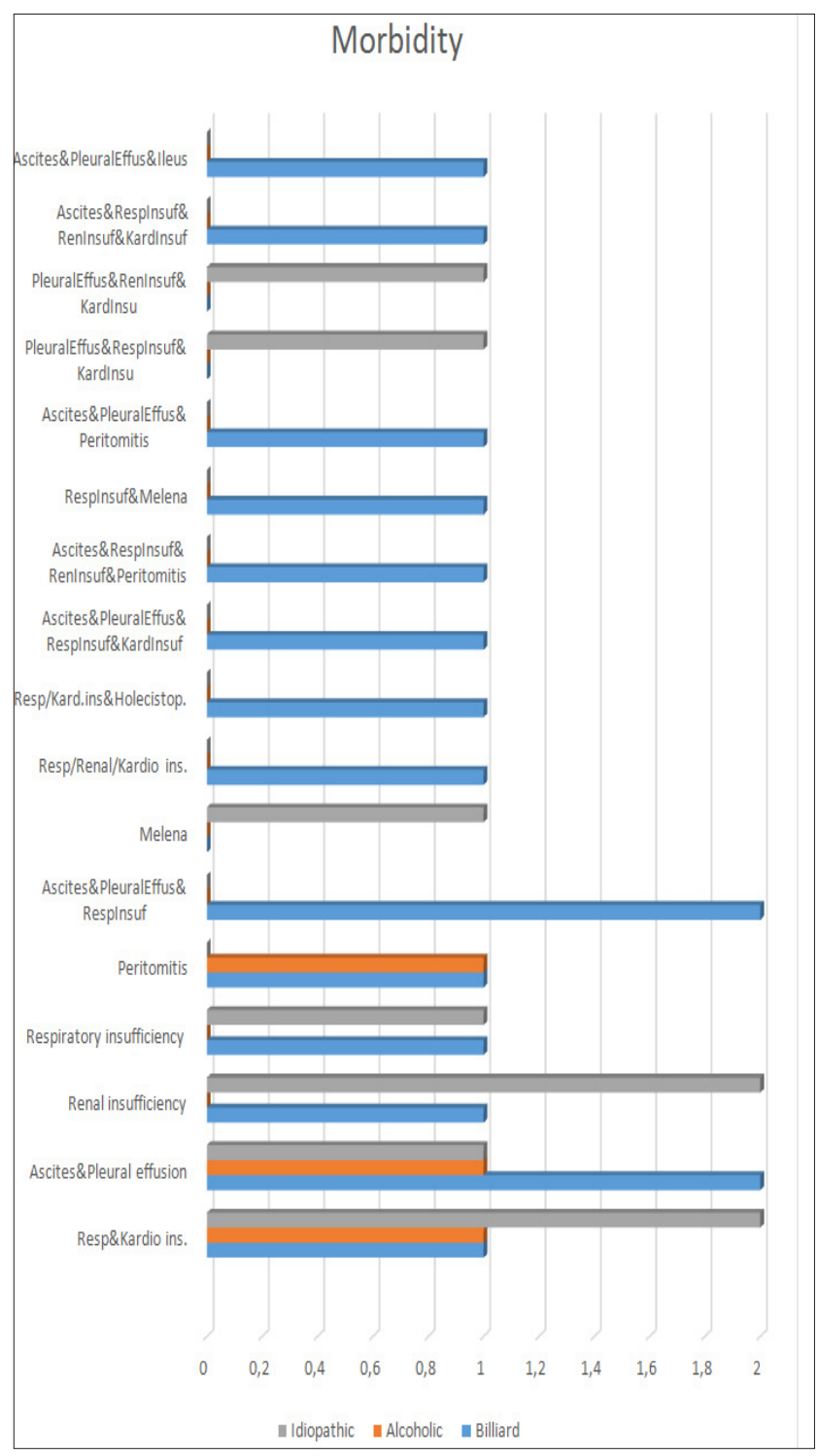

Out of the 66 (44.90\%) patients of the biliary type, the structure was as follows: 18 (12.24\%) were treated surgically, 42 (28.57\%) conservatively, 5 (3.40\%) fatal outcomes, $1(0.68 \%)$ patient was transferred to another department.

There were 25 (17.01\%) patients with alcohol type of AP, and the structure was as follows: 2 (1.36\%) were treated surgically, 22 (14.97\%) conservatively, 1 (o.68\%) death outcome. Of 56 (38.10\%) of patients with idiopathic type AP, the structure was as follows: 7 (4.76\%) were treated surgically, 46 (31.29\%) conservatively, 2 (1.36\%) had a fatal outcome and $10.68 \%$ ) patient was transferred to 
another department. (Chart 4)

\section{Chart 4. Mortality in Billiard, Alcoholic and Idiopathic AP types}

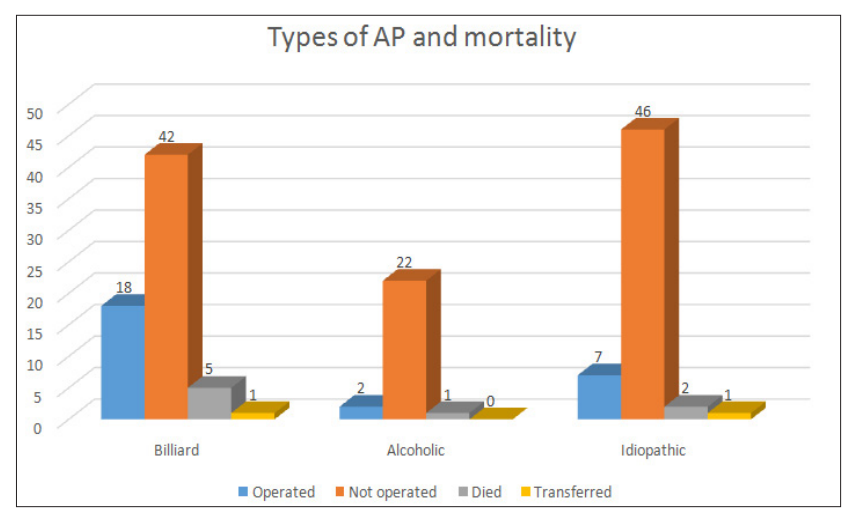

\section{Discussion}

Acute pancreatitis is a disease that requires a quick anamnestic and diagnostic assessment of the state of the disease's severity to predict the course and outcome of the disease as early as possible. Treatment can be conservative and operative. According to the protocol, it begins with the conservative measures that give the best results. In cases of failure through conservative treatment or complications, treatment with hepatic injury is considered. ${ }^{1}$ Indications for an operation are: progressive clinical deterioration, in addition to intensive conservative therapy, pancreatic abscess, uncertainty in clinical diagnosis, correction of the simultaneous hepatobiliary tract disease. ${ }^{2}$

Out of a total of 147 patients treated with acute pancreatitis diagnosed during the period from January 1st 2015 until May 1st 2017. at the Clinic for General and Abdominal Surgery, 110 (74.83\%) were treated conservatively, 27 (18.37\%) operatively, 8 (5.44\%) patients had a mortality outcome, another 2 (1.36\%) patients were treated conservatively and moved to further treatment, to the second division. The obtained statistical results are comparable with the data from available literature. Clinical centers in the European Union, according to modern treatment protocols, also have the largest number of conservatively treated patients. The relationship between conservatively treated and treated patients varies depending on the number of patients involved in the study and varies from country to country. ${ }^{19,23}$

The frequency of complications is most pronounced in the billiary type (12.24\%) followed by idiopathic type (10.20\%) and alcohol type (2.04\%). Out of a total of 147 patients, 66 were billiary (18 with complications,
48 without any complications), 25 alcoholic type (3 with complications, 22 without any complications), 56 idiopathic type (15 with complications, 41 without any complications). The most common complications were: ascites, pleural effusion, renal insufficiency, respiratory insufficiency, cardiac insufficiency and a combination of joint complications in systemic vital organs. According to larger, randomized studies, regardless of whether they are multicentric type or not, the most complications are described in the billiary type, but the type of complications and their duration differ. ${ }^{22-25}$ These facts are explained by a greater degree and the development of health care in the countries of Western Europe. Studies showed a small incidence of complications such as renal and respiratory insufficiency, especially in younger patients. ${ }^{24-27}$

\section{Conclusion}

Patients with biliary type of AP are most common. Of the total number of patients analyzed, the majority of them were treated conservatively, with fewer incidences of the complications and deaths. The most common complications were: ascites, pleural effusion, respiratory and renal insufficiency, as well as a combination of associated complications in the systemic failure of vital organs. Early diagnosis and adequate therapy are crucial for both the outcome of the disease and the financial point of view.

A multidisciplinary approach in the diagnosis and treatment of patients suffering from acute pancreatitis significantly reduces morbidity and mortality. The results of treating patients suffering from acute pancreatitis in the University Clinical centre of the Republic of Srpska in Banja Luka do not deviate significantly from the results of treatment in similar institutions in our region and in the world.

\section{References}

1. Vlajnić Z. Njega hiruških bolesnika sa osnovama hirurgije. Banjaluka: Panevropski Univerzitet Apeiron; 2007;75$82 \mathrm{p}$. PMid:17392540

2. Uhl W, Warshaw A, Imrie C, Bassi C, McKay C, Lankisch $\mathrm{P}$ et al. IAP Guidelines for the Surgical Management of Acute Pancreatitis. Pancreatology. 2002;14(2):565-73. https://doi.org/10.1159/000067684

3. Gulanick M, Myers J. Nursing care plans. 8th edition. Philadelphia:Mosby; 2014;974 p.

4. Bilić A. Bolesti gušterače. Zagreb: Medicinska naklada;1993;101 p.

5. Dominguez-Mufioz JE. Diagnosis of acute pancreatitis: any news or still amylase? In: Buchler M, Uhl E. Acute Pancreatitis:Novel Concepts in Biology and Therapy. 
London:Blackwell Science; 1999; 171 p.

6. Vucelić B. Amilaza-kliničko značenje i interpretacija hiperamilazemije i hiperamilazurije. Liječ Vjes. 1979;101:148-52.

7. Tenner S, Steinberg W. The addmission serum lipase. Amylase ratio differentiates alcoholic from nonalcoholic acute pancreatitis. Am J Gastroenterol. 1992; 87(12):17758.

8. Barauskas G, Svagzdys S, Maleckas A. C-reactive protein in early prediction of pancreatic necrosis. Medicina. 2004;40(2):135-40.

9. Naumovski-Mihalić S, Papa B, Colic-Cvrlje V, Katicic M, Prskalo M, Sabaric B et al. Ultrasonographic parametersprognostic value in acute pancreatitis. Neurol Croatica. 1999;48(1):91-6.

10. Naumovski-Mihalić S, Prkacin I, Scrbec B, Colic-Cvrlje $\mathrm{V}$, Sabaric B, Cetinic N et al. Current management of pancreatic pseudocysts. Neurol Croatica. 2000;49(1):1759.

11. Balthazar EJ, Freeny PC. Contrast enchanced computed tomography in acute pancreatitis. Is it beneficial or harmful? Gastroenterol. 1994;106:152-9. https://doi.org/10.1016/Soo16-5085(94)96077-1

12. Balthazar EJ, Robinson DL, Megibow AJ, Ranson JH. Acute pancreatitis: value of CT in establishing prognosis. Radiology. 1990;174(2):331-6.

https://doi.org/10.1148/radiology.174.2.2296641 PMid:2296641

13. Čolović RB. Akutni pankreatitis. In: Hirurgija pankreasa. Čolović RB, editor. Beograd: Zavod za udžbenike i nastavna sredstva Beograd; 1998. 117-141 p.

14. Arvanitakis M, Koustiani G, Gantzarou A. Staging of severity and prognosis of acute pancreatitis by computed tomography and magnetic resonance imaging-a comparative study. Dig Liv Dis. 2007;39:473-82.

https://doi.org/10.1016/j.dld.2007.01.015 PMid:17363349

15. Büchler MW, Uhl W, Maltfertheiner P, Sarr MG. Acute pancreatitis. Basel: Karger; 2004;1-58 p.

16. NIH-state of the science statement on endoscopic retrograde holangiopancreatography (ERCP) for diagnosis and therapy. NIH Consensens State Sci Statements 2002; 14-16;19(1):1-26.

17. Johnson CD, Abu-Hilal M. Persistent organ failure during the first week as a marker of fatal outcome in acute pancreatitis. Gut. 2004; 53(9):1340-44. https://doi.org/10.1136/gut.2004.039883 PMid:15306596 PMCid:PMC1774183
18. Mithofer K, Mueller PR, Warshaw AL. Interventional and surgical treatment of pancreatic abscess. World J Surg. 1997;21(2):162-8.

https://doi.org/10.1007/s002689900209 PMid:8995072

19. Tenner S. Initial management of acute pancreatitis:critical issues during the first 72 hours. Am J Gastroenterol. 2004;99(12):2489-94.

https://doi.org/10.1111/j.1572-0241.2004.40329.x PMid:15571599

20. Greenberg AJ, Hsu J, Bawazeer M, Marshall J, Friedrich OJ, Nathens A et al. Clinical practice guideline:management of acute pancreatitis. Can J Surg. 2016;59(2):128-140. https://doi.org/10.1503/cjs.015015

PMid:27007094 PMCid:PMC4814287

21. Phillip V, Steiner MJ, Algul H. Early phase of acute pancreatitis:Assessment and management. World J Gastrointest Pathophysiol. 2014; 15;5(3):158-68.

22. Karakayali F. Surgical and interventional management of complications caused by acute pancreatitis. World $\mathrm{J}$ Gastroenterol. 2014 Oct 7;20(37):13412-423. https://doi.org/10.3748/wjg.v20.i37.13412 PMid:25309073 PMCid:PMC4188894

23. Lowe ME, Sevilla WA. Nutritional advice for prevention of acute pancreatitis: review of current opinion. Nutrition and Dietary Supplements 2012;4:71-81. https://doi.org/10.2147/NDS.S29468

24. Buchman AL. Glutamine: commercially essential or conditionally essential? A critical appraisal of the human data. Am J Clin Nutr. 2001;74(1):25-32. https://doi.org/10.1093/ajcn/74.1.25 PMid:11451714

25. Moraes JM, Felga GE, Chebli LA, Franco MB, Gomes CA, Gaburi PD et al. A full solid diet as the initial meal in mild acute pancreatitis is safe and result in a shorter length of hospitalization: results from a prospective, randomized, controlled, double-blind clinical trial. J Clin Gastroenterol 2010;44(7):517-22. https://doi.org/10.1097/MCG.obo13e3181c986b3

26. Gronroos JM, Nylamol EI. Mortality in acute pancreatitis in Turku University Central Hospital 1971-1995. Hepatogastroenterol 1999;46:2572-74.

27. Brown A, Baillargeon JD, Hughes M, Banks P. Can fluid resustitation prevent pancreatic necrosis in severe acute pancreatitis? Pancreatology. 2002;2:104-7. https://doi.org/10.1159/000055899 PMid:12123089 


\section{Komplikacije liječenja akutnog pankreatitisa}

\section{SAŽETAK}

Uvod: Akutni pankreatitis je nespecifično zapaljenje pankreasa koje nastaje zbog intrapankreatične aktivacije njegovih proteolitičkih i lipolitičkih enzima - enzimska lezija. Enzimi koje pankreas normalno izlučuje se aktiviraju u pankreasu i razaraju njegovo tkivo, dovodeći do procesa autolize koji uzrokuje krvarenja i oštećenje krvnih sudova. Enzimska autodigestija počinje lokalnom inflamacijom, edemom, krvarenjem i nekrozom.

Cilj rada: Cilj ovog rada je utvrđivanje učestalosti i komplikacije kod pacijenata oboljelih od akutnog pankreatitisa i na osnovu dobijenih rezultata definisati specifične mjere zdravstvene njege za prevenciju i suzbijanje komplikacija.

Ispitanici i metode: Ovim radom obuhvaćeni su pacijenti oboljeli od akutnog pankreatitisa, liječeni na Klinici za opštu i abdominalnu hirurgiju UKC Republike Srpske u Banjaluci, u periodu od 01.01.2015. do 30.04.2017. Ukupan broj pacijenata liječenih u ovom periodu je 147. Dijagnoza bolesti postavljena je na osnovu iscrpne anamneze pri prijemu (akutni abdominalni bol kod svih pacijenata), laboratorijskih pretraga (kompletne krvne slike, C reaktivni protein, amilaze, lipaza) i dijagnostičkih procedura (ultrazvučnog pregleda abdomena, RTG-a grudnog koša, EKG-a, ERCP-a CT-a i NMR-a). Na osnovu dobijenih podataka iz istorija bolesti, protokola i otpusnih lista izvršene su slijedeće statističke analize: utvrđena je učestalost komplikacija i smrtnost kod bilijarnih, alkoholnih i idiopatskih tipova akutnog pankreatitisa.

Rezultati: Učinjenom obradom utvrđen je najmanji broj laboratorijskih i dijagnostičkih procedura koji uz anamnestičke podatke u kratkom vremenskom roku potvrđuju dijagnozu akutnog pankreatitisa. Vodeći simptom na prijemu bio je jak abdominalnipojasni bol, kod svih ispitanika. U laboratorijskim pretragama dominaraju povišene vrijednosti ukupnog broja leukocita, $\mathrm{C}$ reaktivnog proteina (CRP), te serumske vrijednosti amilaze, lipaze i bilirubina. Rane dijagnostičke procedure, u prvih 48 sati, značajno doprinose smanjenju komplikacija akutnog pankreatitisa. Od ukupno 147 pacijenata sa navedenom dijagnozom, 110 pacijenata je liječeno konzervativno, a 27 operativno. Osam pacijenata je imalo smrtni ishod. Po tipu akutnog pankreatitisa na prvom mjestu je bilijarni oblik, zatim idiopatski i na trećem mjestu alkoholni oblik. Lakša klinička forma akutnog pankreatitisa bila je zastupljena kod 124 pacijenta, a teška kod njih 23. Stopa smrtnosti je 5,44\% kod sva tri klinička oblika.

Zaključak: Rana potvrda dijagnoze akutnog pankreatitisa je osnovni preduslov toka bolesti, smanjenja nastanka mogućih komplikacija i smrtnog ishoda bolesti. Pacijenti koji su liječeni konzervativno imali su manji procenat komplikacija, kraću hospitalizaciju, brži oporavak i bolji kvalitet života u kasnijem periodu. Multidisciplinarni pristup u dijagnostici i liječenju pacijenata oboljelih od akutnog pankreatitisa značajno je smanjio morbiditet i mortalitet. Kvalitetna i sveobuhvatna zdravstvena njega, kao dio multidisciplinarnog timskog rada, doprinosi smanjenju komplikacija bolesti i bržem oporavku pacijenta. Rezultati liječenja pacijenata oboljelih od akutnog pankreatitisa na UKC RS ne odstupaju bitnije od rezultata liječenja u sličnim ustanovama u regionu i svijetu.

Ključne riječi: akutni pankreatitis, liječenje, komplikacije. 